\title{
JUAL BELI RUMAH DINAS PT. PLN (PERSERO) DIHUBUNGKAN DENGAN ASAS KEPASTIAN HUKUM
}

\author{
BUYING AND SELLING HOUSE OFFICE PT. PLN \\ (PERSERO) IS LINKED TO THE PRINCIPLE OF LEGAL \\ CERTAINTY
}

JURNAL

POROS HUKUM

PADJADJARAN

\author{
Henggar Budi Prasetyo; ${ }^{a}$ R. Kartikasari;' ${ }^{\text {b }}$ Yani Pujiwatic
}

P-ISSN: 2715-7202

E-ISSN: 2715-9418

Artikel diterbitkan:

30 November 2020

DOI:

https://doi.org/10.23920/jphp .v2i1.42

Halaman Publikasi:

http://jurnal.fh.unpad.ac.id/i

ndex.php/JPHP/issue/archive

Diterbitkan oleh:

Fakultas Hukum

Universitas Padjadjaran

\begin{abstract}
ABSTRAK
Penghuni sebagai pembeli perlu memperoleh kepastian atas penyerahan hak milik rumah dinas sebagai kewajiban PT PLN (Persero) berdasarkan perjanjian sewa beli. Hal tersebut karena telah disepakati dalam perjanjian sewa beli dan telah diatur dalam peraturan perundangundangan bahwa hak milik rumah dinas wajib diserahkan setelah harga dibayar oleh penghuni kepada PT PLN (Persero. Berdasarkan hal-hal tersebut, maka dapat diidentifikasi permasalahan sebagai berikut: Bagaimana pelaksanaan jual beli rumah dinas milik PT PLN (Persero) dihubungkan dengan asas kepastian hukum? dan Bagaimana perlindungan bagi pembeli atas penyerahan hak milik rumah dinas PT PLN (Persero) dihubungkan dengan asas kepastian hukum? Penelitian ini merupakan penelitian deskriptif analitis dengan pendekatan yuridis normatif. Data-data dalam penelitian ini berupa bahan hukum primer, sekunder dan tersier. Di dalam penelitian ini digunakan analisa data dilaksanakan dengan metode normatif kualitatif. Hasil penelitian menunjukkan bahwa jual beli rumah dinas dilaksanakan berdasarkan perjanjian yang dibuat berdasarkan perundang-undangan. Pembeli PT PLN (Persero) memiliki jaminan kepastian penyerahan hak milik berdasarkan alas hak yang timbul dengan telah dilaksanakannya pembayaran harga rumah dinas.
\end{abstract}

Kata kunci: jual beli; kepastian hukum; rumah dinas

\begin{abstract}
Legal occupants as buyers need to obtain certainty over the transfer of ownership rights to the official residence as an obligation of PT PLN (Persero) based on the lease and purchase agreement. This is because it has been agreed in the lease and purchase agreement and has been regulated in the laws and regulations that the property rights of the official residence must be submitted after the price is paid
\end{abstract}

\footnotetext{
a Magister Ilmu Hukum Fakultas Hukum Universitas Padjadjaran, Jl. Banda No. 42 Bandung, email: niaganjar@yahoo.com.

b Fakultas Hukum Universitas Padjadjaran, Jalan Raya Bandung Sumedang KM. 21 Jatinangor, email: kartikasari@unpad.ac.id

c Fakultas Hukum Universitas Padjadjaran, Jalan Raya Bandung Sumedang KM. 21 Jatinangor, email: y.pujiwati@unpad.ac.id
} 
by the legal occupants to PT PLN (Persero. Based on these things, the following problems can be identified: How the implementation of the sale and purchase of official houses owned by PT PLN (Persero) is connected with the principle of legal certainty? and How is the protection for buyers of the transfer of property rights to the official residence of PT PLN (Persero) related to the principle of legal certainty? This research is a descriptive-analytical study with a normative juridical approach. The data in this study are in the form of primary, secondary, and tertiary legal materials. In this study, data analysis is carried out using a qualitative normative method. The results show that the sale and purchase of official houses are carried out based on agreements made based on legislation. PT PLN (Persero) has a guarantee of certainty of transfer of ownership rights based on rights arising from the payment of official housing prices.

Keywords: legal certainty; official residence; sales

\section{PENDAHULUAN}

Negara memiliki tanggung jawab terhadap pemenuhan kebutuhan rumah bagi setiap warga negara. ${ }^{1}$ Hal tersebut ditegaskan dalam Pasal 28 H Undang-Undang Dasar 1945 bahwa rumah merupakan hak setiap warga negara. ${ }^{2}$ Penyelenggaraan perumahan dan kawasan permukiman menjadi bentuk tanggung jawab negara dalam penyediaan kebutuhan rumah bagi setiap warga negara. ${ }^{3}$

Undang-Undang Nomor 1 Tahun 2011 tentang Perumahan dan Kawasan Permukiman berlaku sebagai dasar penyelenggaraan perumahan dan kawasan permukiman. Penyelenggaraan perumahan dan kawasan permukiman berdasarkan Pasal 1 Angka 6 UU No 1 Tahun 2011 diartikan sebagai kegiatan perencanaan, pembangunan, pemanfaatan, dan pengendalian, termasuk di dalamnya pengembangan kelembagaan, pendanaan dansistem pembiayaan, serta peran masyarakat yang terkoordinasi dan terpadu. Penyelenggaraan perumahan berdasarkan Pasal 19 UU No 1 Tahun 2011 dapat dilaksanakan oleh pemerintah, pemerintah daerah dan/ atau setiap orang.

Badan Usaha Milik Negara atau BUMN dapat turut terlibat dalam penyelenggaraan perumahan dan kawasan permukiman. Keterlibatan tersebut terwujud dalam kebijakan penyediaan perumahan yang disebut dengan istilah rumah dinas. Rumah dinas berdasarkan Pasal 1 Angka 20 Peraturan Menteri Badan Usaha Milik Negara Nomor Per-02/MBU/2010 tentang Tata Cara Penghapusbukuan dan

\footnotetext{
1 Halim, (2001), Hukum Pemukiman, Perumahan dan Rumah Susun, Jakarta: Doa\& Karma, hlm. 42.

2 Santoso, (2014), Hukum Perumahan, Jakarta: Kencana, hlm. 2.

${ }^{3}$ Kurniati. (2014), "Pemenuhan Hak atas Perumahan dan Kawasan Permukiman yang Layak dan Penerapannya Menurut Kovenan Internasional tetang Hak-Hak Ekonomi, Sosial dan Budaya di Indonesia", Padjadjaran Jurnal Ilmu Hukum, Vol. 1 No. 1, hlm. 80.
} 
Pemindahtanganan Aktiva Tetap Badan Usaha Milik Negara selanjutnya disebut Permen BUMN Per-02/MBU/2010 diartikan sebagai rumah milik BUMN.

Penyediaan rumah dinas dilaksanakan dengan berpedoman pada ketentuan rumah negara sebagaimana dimuat dalam UU No 1 Tahun 2011. Rumah negara berdasarkan Pasal 1 Nomor 12 UU No 1 Tahun 2011 diartikan sebagai rumah yang dimiliki negara dan berfungsi sebagai tempat tinggal atau hunian dan sarana pembinaan keluarga serta penunjang pelaksanaan tugas pejabat dan/atau pegawai negeri. Ketentuan lebih lanjut berkaitan dengan rumah negara dimuat dalam Peraturan Pemerintah Nomor 40 Tahun 1994 tentang Rumah Negara dan perubahan dalam Peraturan Pemerintah Nomor 31 Tahun 2005 selanjutnya disebut PP No 40 Tahun 1994.

Penyediaan rumah dinas diperuntukan sebagai tempat tinggal bagi karyawan BUMN yang bersangkutan. Istilah penghuni selanjutnya disebut penghuni berdasarkan Pasal 1 Angka 22 Permen BUMN Per-02/MBU/2010 digunakan untuk penyebutan karyawan BUMN yang ditunjuk serta diberikan izin dari BUMN yang bersangkutan atau instansi yang berwenang untuk menghuni rumah dinas. Rumah dinas berdasarkan Pasal 51 ayat (2) UU No 1 Tahun 2011 dapat dihuni selama jangka waktu penugasan yang diberikan oleh BUMN yang bersangkutan.

BUMN tidak sepenuhnya terikat ketentuan rumah negara sebagaimana dimuat dalam UU No 1 Tahun 2011. ${ }^{4}$ Hal tersebut karena berdasarkan Pasal 21 ayat (8) UU No 1 Tahun 2011 ketentuan rumah negara hanya berlaku bagi pemerintah dan/ atau pemerintah daerah tidak termasuk BUMN. ${ }^{5}$ Ketentuan rumah negara dapat berlaku pada BUMN sepanjang tidak diatur dalam Permen BUMN Per-02/MBU/2010 dan telah diakomodir dalam penyediaan rumah dinas oleh BUMN yang bersangkutan. Hal tersebut karena persamaan dalam hal tujuan penghunian antara rumah dinas dengan rumah negara sebagai pendukung tugas-tugas kedinasan.

Rumah dinas sebagai kekayaan atau aset berdasarkan konsideran Permen BUMN Per-02/MBU/2010 dituntut untuk dapat dikelola oleh BUMN yang bersangkutan guna meningkatkan produktivitas serta menciptakan nilai tambah. ${ }^{6}$ Pengelolaan rumah dinas berdasarkan Pasal 19 Permen BUMN Per-02/MBU/2010 dapat dilaksanakan sesuai

\footnotetext{
${ }^{4}$ Hartini, (2017), BUMN Persero: Konsep Keuangan Negara dan Hukum Kepailitan di Indonesia, Setara Press: Malang, hlm. 69.

5 Rokfa, (2020), "Kedudukan Hukum Kekayaan BUMN Persero dalam Pelaksanaan Sita Umum sebagai Akibat Terjadinya Kepailitan", Jurnal Ilmu Kenotariatan, Volume 1 Issue 1, hlm. 46.

6 Adhari, (2015), "Eksistensi BUMN sebagai Korporasi yang Dikuasai Negara", Dialogia Iuridica, Volume 7 Nomor 1, hlm. 35.
} 
dengan peruntukan sebagai perumahan ataupun dapat didayagunakan dalam bentuk lain guna memberikan keuntungan bagi perusahaan yang bersangkutan. Rumah dinas dapat dihapus dari daftar aset dan dialihkan dalam hal tidak lagi dibutuhkan dan tidak prospektif untuk dikembangkan oleh BUMN yang bersangkutan.

Rumah dinas diprioritaskan dialihkan oleh BUMN yang bersangkutan kepada penghuni. Hal tersebut diatur dalam Pasal 20 ayat (1) Permen BUMN Per-02/MBU/2010 bahwa rumah dinas ditawarkan terlebih dahulu kepada penghuni. ${ }^{7}$ Penghuni berdasarkan Pasal 20 ayat (2) diberikan waktu 30 (tiga puluh) hari untuk menyatakan kesediaan untuk membeli rumah dinas dari BUMN yang bersangkutan.

Rumah dinas dapat dialihkan setelah diperoleh persetujuan dari pengurus yang berwenang pada BUMN yang bersangkutan. Persetujuan tersebut berdasarkan Pasal 15 Permen BUMN Per-02/MBU/2010 diberikan oleh Dewan Pengawas atau Dewan Komisaris atau Menteri BUMN/RUPS sesuai dengan anggaran dasar BUMN yang bersangkutan. ${ }^{8}$ Persetujuan tersebut diberikan berdasarkan usulan pengalihan rumah dinas yang diajukan oleh BUMN yang bersangkutan. ${ }^{9}$

Rumah dinas dialihkan oleh BUMN kepada penghuni dengan cara penjualan. Hal tersebut dilaksanakan berdasarkan Pasal 9 Permen BUMN Per-02/MBU/2010 bahwa pengalihan rumah dinas dilaksanakan dengan penjualan dengan cara penunjukan langsung. Penunjukan langsung berdasarkan Pasal 1 Nomor 19 Permen BUMN Per02/MBU/2010 diartikan sebagai penjualan Aktiva Tetap yang dilakukan secara langsung kepada satu calon pembeli.

Jual beli rumah dinas secara umum dilaksanakan oleh BUMN yang bersangkutan berdasarkan ketentuan jual beli yang dimuat dalam Kitab Undang-Undang Hukum Perdata selanjutnya disebut KUHPerdata. Jual beli berdasarkan Pasal 1457 KUHPerdata diartikan sebagai suatu persetujuan atau kesepakatan dengan mana pihak yang satu mengikatkan dirinya untuk menyerahkan suatu barang dan pihak yang lain untuk membayar harga yang dijanjikan. ${ }^{10}$ BUMN dan penghuni sebagai pihak dalam jual beli rumah dinas dengan mempertimbangkan perundang-undangan memiliki keleluasan

\footnotetext{
7 G.M. Intan et.al, (2019), “Kepemilikan Rumah Dinas oleh Purnawirawan TNI Berdasarkan Perundang-Undangan”, Law Review, Vol. XIX, No. 1, hlm. 101.

8 M.I.B Barnok, (2011), “Tanggung Jawab Direksi dalam Pelepasan Aset Tidak Bergerak pada Badan Usaha Milik Negara," Tesis. Fakultas Hukum Universitas Sumatera Utara, Medan, hlm. 146.

9 Kusmono, (2016), "Pembelaan melalui Prinsip-Prinsip Business Judgement Rule Bagi Direksi BUMN Persero Bila Terjadi Kerugian", Ilmu Artha, Vol. 3, hlm. 39.

10 Subekti, (2014), Hukum Perjanjian, Jakarta: Intermasa, hlm. 80
} 
dalam pelaksanaan jual beli dengan berlakunya asas kebebasan berkontrak berdasarkan Pasal 1338 KUHPerdata. Secara khusus penjualan rumah dinas dilaksanakan berdasarkan Pasal 31 ayat (1) Permen BUMN Per-02/MBU/2010 ditetapkan dilaksanakan dengan pembayaran tunai. Selanjutnya, penyerahan hak milik dilaksanakan sekaligus pada hari pembayaran harga rumah dinas. Berdasarkan Pasal 31 ayat (2) Permen BUMN Per-02/MBU/2010 Menteri BUMN/RUPS dapat menetapkan mekanisme pembayaran selain tunai berdasarkan usulan dari Direksi.

Jual beli sebagai perbuatan hukum berdasarkan peraturan perundang-undangan menimbulkan akibat berupa perikatan bagi para pihak. Perikatan pokok dalam jual beli berupa penyerahan dan pembayaran harga rumah dinas. BUMN sebagai penjual dibebankan kewajiban penyerahan hak milik kepada penghuni sedangkan penghuni sebagai pembeli dibebankan kewajiban pembayaran harga kepada penjual.

Kebijakan pengalihan rumah dinas pada BUMN salah satunya dilaksanakan oleh PT PLN (Persero). PT PLN (Persero) merupakan Badan Usaha yang dibentuk oleh negara melalui Peraturan Pemerintah Nomor 23 Tahun 1994 tentang Pengalihan Bentuk Perusahaan Umum (Perum) Listrik Negara menjadi Perusahaan Perseroan (Persero). PT PLN (Persero) berdasarkan Pasal 2 PP No 23 Tahun 1994 memiliki tugas untuk menyediakan tenaga listrik bagi kepentingan umum dan sekaligus memupuk keuntungan berdasarkan prinsip pengelolaan Perusahaan;

Rumah dinas milik PT PLN (Persero) dialihkan kepada penghuni dengan cara jual beli. Jual beli rumah dinas antara PT PLN (Persero) dengan penghuni disepakati digunakan mekanisme sewa beli. ${ }^{11} \mathrm{Hal}$ tersebut serupa dengan cara pengalihan rumah negara sebagaimana diatur dalam Pasal 18 PP No 40 Tahun 1994.

Sewa beli berdasarkan Pasal 22 ayat (3) PP No 40 Tahun 1994 merupakan jual beli dengan pembayaran yang dilaksanakan dengan cara diangsur. Selain itu, setiap pembayaran angsuran harga rumah dinas juga diperhitungkan sebagai pembayaran sewa rumah dinas yang telah dikuasai atau dihuni oleh penghuni. ${ }^{12}$ Penyerahan hak milik rumah dinas berdasarkan disepakati oleh PT PLN (Persero) dan penghuniPasal 1478 KUHPerdata dilaksanakan setelah harga dibayar oleh penghuni kepada PT PLN

\footnotetext{
${ }^{11}$ Kurniati, (2014), "Pemenuhan Hak atas Perumahan dan Kawasan Permukiman yang Layak dan Penerapannya Menurut Kovenan Internasional tetang Hak-Hak Ekonomi, Sosial dan Budaya di Indonesia", Padjadjaran Jurnal Ilmu Hukum, Vol. 1 No. 1, hlm. 80.

${ }^{12}$ Bawarodi, (2014), “Penerapan Perjanjian Sewa Beli di Indonesia dan Akibat Hukumnya”, Lex Privatum, Vol. II, No. 3, hlm. 13.
} 
(Persero). ${ }^{13}$ Selain itu, diatur dalam Pasal 1478 KUHPerdata bahwa kewajiban penyerahan hak milik timbul ketika telah terlaksana pembayaran harga sesuai kesepakatan.

PT PLN (Persero) memiliki kewajiban untuk menyerahan hak milik rumah dinas baik berupa tanah dan bangunan gedung sebagai satu kesatuan dengan disertai buktibukti hak milik kepada penghuni dengan telah dipenuhinya pembayaran harga. ${ }^{14}$

Penyerahan hak milik rumah dinas berdasarkan Pasal 1459 KUHPerdata menjadi syarat bagi penghuni untuk memperoleh hak milik. Hal tersebut karena hak milik tidak serta merta diperoleh penghuni dengan pembayaran pelunasan harga rumah dinas. ${ }^{15}$ Hak milik diperoleh setelah dilaksanakan penyerahan dari PT PLN (Persero) kepada penghuni berdasarkan perundang-undangan. 16

Penyerahan hak milik rumah dilaksanakan dengan pembuatan perjanjian oleh PT PLN (Persero) dan penghuni. Perjanjian penyerahan dibuat sebagai tindak lanjut atas perjanjian sewa beli rumah dinas yang telah disepakati oleh PT PLN (Persero) dan penghuni. Hal tersebut diatur dalam Pasal 23 Peraturan Pemerintah Nomor 24 Tahun 1997 tentang Pendaftaran Tanah selanjutnya disebut PP No 24 Tahun 1997 sebagai peraturan pelaksana UU No 5 Tahun 1960 bahwa penyerahan hak milik rumah dinas dilaksanakan dengan pembuatan akta atau perjanjian dihadapan PPAT.17 Perjanjian penyerahan hak milik rumah dinas dibuat setelah dicapai kesepakatan antara PT PLN (Persero) dan penghuni. Hal tersebut karena perjanjian penyerahan hak milik rumah dinas merupakan perjanjian baru terlepas adanya keterkaitan sebagai tindak lanjut perjanjian sewa beli yang telah disepakati oleh PT PLN (Persero) dan penghuni.

Persyaratan kesepakatan dalam pembuatan perjanjian penyerahan hak milik rumah dinas berakibat timbulnya ketidakpastian terutama bagi penghuni. Hal tersebut karena apabila persyaratan kesepakatan belum terpenuhi berakibat pada tertundanya penyerahan hak milik rumah dinas dari PT PLN (Persero) kepada penghuni. Perlindungan hukum diperlukan bagi penghuni atas kondisi tersebut karena yang telah

\footnotetext{
${ }^{13}$ Paramita et.al, (2016), “Wanprestasi dalam Perjanjian Pengikatan Jual Beli Tahap dan Bangunan (Studi Penelitian pada Pengembang Kota Semarang)", Diponegoro Law Journal, Volume 5 Nomo 3, hlm. 19.

${ }^{14}$ A.P.D Amalia, "Analisis Yuridis Terhadap Perjanjian Sewa Beli Rumah Negara di Kota Medan," Tesis, Fakultas Hukum Universitas Sumatera Utara, Medan, hlm. 101

${ }^{15}$ Agustina, (2017), "Kedudukan Hukum Sewa Beli dalam Peralihan Hak atas Tanah dan Bangunan Studi atas Sewa Beli antara PT PLN (Persero) Wilayah Sumbagut dengan Karyawan," Tesis, Fakultas Hukum Universitas Sumatera Utara. Medan, hlm. 110.

${ }^{16}$ A.R Rifan et.al, (2017), “Kesadaran Hukum Masyarakat dalam Jual Beli Tanah dengan Akta PPAT di Kecamatan Tinanggea Kabupaten Konawe Sulawesi Tenggara", Jurnal Akta, Vol. 4 No. 3, hlm. 428.

${ }^{17}$ Muhammad (1982), Hukum Perikatan, Bandung: Alumni, hlm. 107.
} 
dipenuhinya kewajiban pembayaran harga rumah dinas. ${ }^{18}$ Perjanjian yang dibuat antara PT PLN (Persero) dengan penghuni seharusnya memberikan kepastian terhadap pelaksanaan sewa beli rumah dinas sesuai Pasal 1338 KUHPerdata. ${ }^{19}$ Hal-hal yang telah diuraikan di atas menjadi dasar penelitian tentang pengalihan rumah dinas oleh PT PLN (Persero) kepada penghuni dengan cara sewa beli.

Adapun rumusan permasalahan sebagai berikut:

1. Bagaimana pelaksanaan penjualan rumah dinas PT PLN (Persero) dihubungkan dengan asas kepastian hukum?

2. Bagaimana perlindungan terhadap hak pembeli rumah dinas PT PLN (Persero) dihubungkan dengan asas kepastian hukum?

\section{METODE PENELITIAN}

Metode penelitian yang digunakan dalam penelitian ini adalah yuridis normatif atau penelitian hukum yang dilaksanakan dengan penelitian kepustakaan. ${ }^{20}$ Spesifikasi penelitian ini adalah deskriptif analitis dilaksanakan dengan menggambarkan faktafakta untuk guna memperoleh gambaran yang menyeluruh dan sistematis tentang pengalihan rumah dinas PT PLN (Persero) dengan cara sewa beli. ${ }^{21}$ Sumber data yang digunakan dalam penelitian adalah data sekunder. Data sekunder tersebut dibedakan dalam 3 (tiga) golongan terdiri dari: bahan-bahan hukum primer berupa peraturan perundang-undangan, bahan-bahan hukum sekunder berupa doktrin (pendapat para ahli hukum), serta bahan-bahan hukum tersier berupa kamus hukum atau ensiklopedia. Alat pengumpulan data yang digunakan dalam penelitian ini adalah studi dokumen. Studi dokumen dilaksanakan dengan penelaahanbahan-bahan kepustakaan yang meliputi bahan hukum primer, bahan hukum sekunder dan bahan hukum tersier. Analisa data dalam penelitian ini dilaksanakan dengan metode normatif kualitatif. ${ }^{22}$ Normatif karena penelitian ini bertitik tolak dari peraturan perundang-undangan yang ada sebagai hukum positif. Kualitatif karena merupakan analisis dan penelaahan yang

\footnotetext{
18 Angelina, (2012), "Tinjauan Yuridis Terhadap Pembatalan Perjanjian Pengikatan Jual Beli (PPJB) yang Dibuat oleh Notaris yang Telah Sesuai dengan Wilayah Kewenangannya (Studi Kasus Putusan Pengadilan Negeri Jakarta utara nomor 260/PDT.G/2002/PN.JKT.PST," Tesis. Fakultas Hukum Universitas Indonesia.Depok., hlm. 70.

${ }^{19}$ Salman et.al, (2013), Kumpulan Karya Tulis Mochtar Kusumaatmaja tentang konsep-konsep hukum dalam pembangun, Bandung: Alumni, hlm. 4.

${ }^{20}$ Soekanto, (2010), Penelitian Hukum Normatif Suatu Tinjauan Singkat, Jakarta: Raja Grafindo Persada, hlm. 23.

${ }^{21}$ Sugiyono, (2009), Metode Penelitian Kualitatif, Bandung: Alfabeta, hlm. 29.

22 Zainudin Ali, (2011), Metode Penelitian Hukum, Jakarta, Sinar Grafika, hlm 105.
} 
mendalam, yang tidak hanya berpegang pada statistik, namun lebih menitikberatkan pada perilaku dan interaksi dari nilai-nilai dalam suatu proses realita sosial.

\section{PEMBAHASAN}

\section{Penjualan Rumah Dinas PT PLN (Persero) kepada Penghuni Dihubungkan Asas Kepastian Hukum}

BUMN sebagai pelaku ua memiliki orientasi untuk mengejar keuntungan. ${ }^{23} \mathrm{Hal}$ tersebut diatur dalam Pasal 2 ayat (1) UU No 19 Tahun 2003 sebagai salah satu maksud dan tujuan pendirian BUMN. Keuntungan diperoleh BUMN melalui partisipasi dalam penyelenggaraan kegiatan perekonomian berupa penyediaan barang dan/ atau jasa.

Keuntungan yang diperoleh BUMN erat kaitannya dengan pengelolaan kekayaan atau aset. Aset merupakan modal bagi BUMN dalam pelaksanaan suatu kegiatan ua tertentu. Berdasarkan Permen BUMN Per-02/MBU/2010 ditegaskan bahwa melalui pengelolaan aset, BUMN dituntut untuk dapat meningkatkan produktivitas serta menciptakan nilai tambah. Aset dapat dipindahtangankan atau dialihkan apabila tidak dapat dimanfaatkan oleh BUMN yang bersangkutan. Hal tersebut dapat dilaksanakan oleh BUMN yang bersangkutan berdasarkan Permen BUMN Per-02/MBU/2010 sebagai bentuk kebijakan bisnis berdasarkan bussiness judgement rule. ${ }^{24}$

PT PLN (Persero) sebagai salah BUMN telah melaksanakan pengalihan aset berupa rumah dinas. Rumah dinas merupakan salah satu jenis aset pada BUMN sebagaimana diatur dalam Permen BUMN Per-02/MBU/2010. Aset rumah dinas terdiri dari tanah dan bangunan gedung dengan fungsi sebagai tempat tinggal bagi karyawan yang ditunjuk oleh PT PLN (Persero) sebagai penghuni. ${ }^{25}$ Selain itu, berdasarkan Pasal 19 ayat (2) Permen BUMN Per-02/MBU/2010 dapat dikembangkan atau didayagunakan oleh PT PLN (Persero) guna memberikan pendapatan tambahan.

Pengalihan rumah dinas oleh PT PLN (Persero) dilaksanakan dengan berpedoman pada Pasal 19 ayat (1) Permen BUMN Per-02/MBU/2010. Rumah dinas dapat dialihkan setelah dipenuhi persyaratan sebagaimana dimuat Pasal 19 ayat (2) Permen BUMN Per02/MBU/2010, terdiri dari:

\footnotetext{
${ }^{23}$ P. Agung, (2018), "Masalah Keagenan dan Kepemilikan Pemerintah Serta Dampak Keuangan Negara atas Implementasi ISAJK 8 (Studi Kasus PT PLN (Persero)", Simposium Nasional Keuangan Negara, Vol. 1, No, 1, hlm. 698. ${ }^{24}$ Ibid, hlm. 79.

${ }^{25}$ Hartini, Op. Cit, hlm. 117.
} 
1. sudah tidak dipergunakan lagi oleh perusahaan;

2. tidak prospektif dikembangkan untuk memberikan penghasilan yang lebih menguntungkan; atau

3. diperuntukkan untuk Kepentingan Umum sesuai dengan ketentuan peraturan perundang-undangan yang berlaku.

Selain itu, PT PLN (Persero) dapat berpedoman pada PP No 40 Tahun 1994 tentang Rumah Negara. Hal tersebut karena terdapat keterkaitan antara rumah dinas dengan rumah negara ditinjau dari segi penghunian. Selain berpedoman pada ketentuan peraturan perundangan, PT PLN (Persero) wajib berpedoman pada Good Corporate Governance dalam pelaksanaan pengalihan rumah dinas. ${ }^{26}$

Pengalihan rumah dinas ditetapkan sebagai kebijakan atas dasar usulan dari Pemimpin Unit Bisnis PT PLN (Persero). Pemimpin Unit Bisnis merupakan sebutan untuk pemangku jabatan struktural yang memiliki kewenangan dan sebagai penanggung jawab Unit Bisnis di lingkungan PT PLN (Persero).27 Usulan pengalihan rumah dinas dapat diusulkan pemimpin unit bisnis kepada Direksi apabila telah dilengkapi dengan persyaratan sesuai kebijakan ditetapkan Direksi PT PLN (Persero), sebagai berikut:

1. Rumah dinas telah dimiliki PT PLN (Persero) sekurang-kurangnya sepuluh tahun

2. Penghuni sebagai calon pembeli memenuhi syarat-syarat, sebagai berikut:

a. Memegang Surat Izin Penempatan (SIP) atau izin tertulis lainnya yang sesuai dengan ketentuan yang berlaku;

b. Telah bekerja pada PLN sekurang-kurangnya selama 10 (sepuluh) tahun;

3. Belum pernah membeli rumah dari PT PLN (Persero);

4. Telah menempati rumah dinas milik PT PLN (Persero) berturut-turut selama 2 (dua) tahun.

Usulan pengalihan rumah dinas yang telah dinyatakan lengkap oleh Direksi diajukan kepada Dewan Komisaris serta Rapat Umum Pemegang am untuk diajukan persetujuan. Selanjutnya, terhadap usulan pengalihan yang telah disetujui oleh RUPS ditindaklanjuti dengan penetapan penjualan rumah dinas oleh Direksi. ${ }^{28}$

\footnotetext{
${ }^{26}$ Orchad, "Penerapan Good Corporate Governance dalam Upaya Mewujudkan BUMN yang Berbudaya", Jurnal Hukum Samudera Keadilan, Volume 11 Nomor 2, hlm. 270.

${ }^{27}$ Miru et.al, (2012), Hukum Perikatan: Penjelasan Makna Pasal penghuni Pasal 1313 sampai 1456 BW, Jakarta: Rajawali Pers, hlm. 65.

${ }^{28}$ Wijaya, (2015), "Pertanggungjawaban Pengurusan Badan Usaha Milik Negara Terhadap Kerugian Keuangan Negara pada Pengelolaan Persero", Jurnal Ilmiah Mahasiswa Universitas Surabaya, Vol. 4 No. 2 Tahun 2015, hlm. 30.
} 
Rumah dinas yang telah ditetapkan oleh Direksi untuk dialihkan, terlebih dahulu ditawarkan kepada penghuni. ${ }^{29}$ Hal tersebut sesuai dengan Pasal 20 ayat (2) Permen BUMN Per-02/MBU/2010 bahwa penghuni diprioritaskan menerima pengalihan rumah dinas. Istilah penghuni selanjutnya disebut penghuni digunakan untuk penyebutan karyawan PT PLN (Persero) sebagai penerima hak penghunian rumah dinas. Istilah penghuni selanjutnya disebut penghuni digunakan untuk penyebutan penerima hak penghunian rumah dinas dari PT PLN (Persero). ${ }^{30}$ Penghuni dapat mengajukan permohonan pembelian, apabila sepakat terhadap penawaran rumah dinas dari PT PLN (Persero). ${ }^{31}$

PT PLN (Persero) dalam pelaksanaan jual beli rumah dinas diwakili oleh Direksi. Direksi menjadi pihak yang berwenang mewakili PT PLN (Persero) atas dasar peraturan perundang-undangan dan anggaran dasar. ${ }^{32}$ Selain itu, PT PLN (Persero) dalam pelaksanaan jual beli rumah dinas dapat diwakili oleh Pemimpin Unit Bisnis atas dasar surat kuasa. Hal berbeda berlaku bagi penghuni dimana pelaksanaan jual beli rumah dinas dapat dilaksanakan secara langsung. Hal tersebut karena penghuni tergolong sebagai perorangan yang secara langsung memiliki kewenangan melakukan suatu perbuatan hukum.

Rumah dinas berdasarkan Permen BUMN Per-02/MBU/2010 dapat dilaksanakan pengalihan oleh PT PLN (Persero) dengan cara-cara penjualan selanjutnya disebut jual beli. Jual beli berdasarkan Pasal 1 Angka 14 Permen BUMN Per-02/MBU/2010 diartikan sebagai tindakan pengalihan dengan menerima pembayaran dalam bentuk uang. Jual beli secara umum telah diatur dalam KUHPerdata sehingga tergolong sebagai perjanjian dengan nama khusus. Ketentuan-ketentuan jual beli dalam KUHPerdata berlaku mengikat bagi PT PLN (Persero) dan penghuni sepanjang tidak disepakati untuk dikesampingkan.

Kesepakatan menjadi dasar dalam pelaksanaan pengalihan rumah dinas oleh PT PLN (Persero) dan penghuni. Hal tersebut diatur dalam Pasal 1313 KUHPerdata bahwa atas dasar kesepakatan dapat dibuat suatu pengikatan oleh satu orang atau lebih dengan satu orang lain atau lebih. PT PLN (Persero) dan penghuni memiliki kebebasan dalam penentuan ketentuan-ketentuan untuk disepakati sebagai dasar pelaksanaan

\footnotetext{
${ }^{29}$ Sidabalok, Op. Cit, hlm. 77

${ }^{30}$ Hamzah, (1990), Hukum Perumahan. Jakarta: Rineka Cipta, hlm. 55.

31 Subekti, Op. Cit, hlm. 20.

32 Rahardjo (2010), Ilmu Hukum, Bandung: Citra Aditya Bakti, hlm. 40.
} 
pengalihan rumah dinas. Hal tersebut merupakan wujud dari berlakunya asas kebebasan berkontrak sebagaimana tersirat dalam Pasal 1388 KUHPerdata. 33

Pengalihan rumah dinas oleh PT PLN (Persero) dan penghuni diantara dilaksanakan dengan cara sewa beli. ${ }^{34}$ Hal tersebut ditentukan berdasarkan kesepakatan antara PT PLN (Persero) dan penghuni yang dituangkan dalam perjanjian tertulis. Penggunaan Sewa beli dalam pengalihan rumah dinas diakomodir oleh PT PLN (Persero) dan penghuni dari ketentuan-ketentuan yang berlaku untuk pengalihan rumah negara sebagaimana diatur dalam Pasal 18 Peraturan Pemerintah Nomor 40 Tahun 1994 tentang Rumah Negara dengan perubahan Peraturan Pemerintah Nomor 31 Tahun 2005 selanjutnya disebut PP No 40 Tahun 1994. Ketentuan sewa beli untuk rumah negara sebagaimana diatur dalam PP No 40 Tahun 1994 berlaku bagi PT PLN (Persero) dan penghuni sepanjang telah disepakati dan dicantumkan dalam perjanjian.

Sewa beli sebagai suatu perjanjian tidak dikenal dan diatur dalam KUHPerdata sehingga dikatakan sebagai perjanjian tidak bernama. Meskipun sewa beli tergolong sebagai perjanjian tidak bernama, akan tetapi berdasarkan Pasal 1319 KUHPerdata PT PLN (Persero) dan penghuni terikat ketentuan-ketentuan yang berlaku umum dalam KUHPerdata. Ketentuan-ketentuan umum yang diatur dalam KUHPerdata berlaku bagi PT PLN (Persero) dan penghuni karena terpenuhi kualifikasi hukum sebagai akibat dari perjanjian yang telah disepakati.

PT PLN (Persero) dan penghuni secara tidak langsung terikat ketentuanketentuan jual beli. Hal tersebut karena sewa beli rumah dinas yang telah disepakati memenuhi kualifikasi sebagai perbuatan jual beli sebagaimana diatur dalam Pasal 1457 KUHPerdata. Hal tersebut tercermin dari ketentuan-ketentuan yang disepakati oleh PT PLN (Persero) dan penghuni diantaranya berupa penyerahan rumah dinas serta pembayaran harga. ${ }^{35}$

Harga jual beli rumah dinas dinas disepakati oleh PT PLN (Persero) dan penghuni berdasarkan hasil penaksiran pihak ketiga baik oleh perusahaan penilai publik atau tim penaksir yang dibentuk oleh Direksi atau penerima kuasanya yang berwenang. ${ }^{36} \mathrm{Hal}$ tersebut dilaksanakan sesuai dengan pedoman sebagaimana dimuat dalam Permen BUMN Per-02/MBU/2010. PT PLN (Persero) dan penghuni sepakat bahwa harga

\footnotetext{
33 Subekti, Op. Cit, hlm. 13.

${ }^{34}$ Ibid, hlm. 14.

35 Subekti, Op. Cit, hlm. 79.

${ }^{36}$ Hasbullah, (2002), Hukum Kebendaan Perdata, Jakarta: Ind.hill, hlm. 28.
} 
dibayar secara bertahap selanjutnya disebut angsuran dengan jangka waktu paling lama 5 (lima) tahun.

Selain itu, PT PLN (Persero) dan penghuni secara tidak langsung terikat ketentuan-ketentuan sewa menyewa sebagaimana diatur dalam KUHPerdata. Hal tersebut karena sewa beli rumah dinas yang telah disepakati memenuhi kualifikasi untuk dikatakan sebagai sewa menyewa berdasarkan Pasal 1548 KUHPerdata. Hal tersebut tercermin dari ketentuan-ketentuan yang disepakati dalam perjanjian sewa beli berupa pemberian hak untuk menikmati atau hak penghunian rumah dinas disertai dengan pembayaran suatu harga tertentu. Sewa menyewa disepakati oleh PT PLN (Persero) dan penghuni berlangsung sampai dengan hak milik rumah dinas diserahkan atau apabila ada kesepakatan perihal pengakhiran perjanjian sewa beli.

Penghuni memperoleh hak milik rumah dinas setelah dilaksanakan penyerahan hak milik oleh PT PLN (Persero). Pemenuhan kewajiban perjanjian sewa beli rumah dinas oleh penghuni baru melahirkan hak untuk menuntut penyerahan hak milik sebagai kewajiban PT PLN (Persero). Hal tersebut diatur dalam Pasal 1459 KUHPerdata bahwa hak milik berlum beralih sebelum dilaksanakan penyerahan. Sewa beli berdasarkan Pasal 584 KUHPerdata menjadi peristiwa perdata sebagai dasar peralihan hak milik.

Penyerahan hak milik rumah dinas disepakati oleh PT PLN (Persero) dan penghuni dilaksanakan setelah kewajiban pembayaran harga terpenuhi. Selain itu, timbulnya hak atas penyerahan hak milik rumah dinas dari PT PLN (Persero) kepada penghuni timbul berdasarkan Pasal 1478 KUHPerdata. Diatur dalam Pasal 1478 KUHPerdata hak milik suatu barang yang wajib diserahkan kepada pembeli ketika pembayaran harga telah terpenuhi.

Penyerahan hak milik rumah dinas dilaksanakan berdasarkan UU No 5 Tahun 1960 melalui kegiatan pendaftaran tanah. Hak tersebut dilaksanakan dengan maksud dan tujuan untuk memberikan pengakuan secara hukum bagi penghuni sebagai pemegangnya. Pendaftaran tanah diatur dalam Pasal 1 Angka 1 PP No 24 Tahun 1997 sebagai peraturan pelaksana UU No 5 Tahun 1960 diartikan sebagai rangkaian kegiatan yang dilakukan oleh Pemerintah secara terus menerus, berkesinambungan dan teratur, meliputi pengumpulan, pengolahan, pembukuan, dan penyajian serta pemeliharaan data fisik dan data yuridis, dalam bentuk peta dan daftar, mengenai bidang-bidang tanah dan satuan-satuan rumah susun, termasuk pemberian surat tanda bukti haknya 
bagi bidang-bidang tanah yang sudah ada haknya dan hak milik atas satuan rumah susun serta hak-hak tertentu yang membebaninya.

Pendaftaran tanah berdasarkan Pasal 23 PP No 24 Tahun 1997 dapat dilaksanakan setelah dibuat perjanjian penyerahan hak milik antara PT PLN (Persero) dan penghuni dihadapan PPAT. ${ }^{37}$ Perjanjian penyerahan hak milik rumah dinas merupakan suatu perjanjian baru, meskipun dibuat sebagai tindak lanjut dari perjanjian sewa beli yang telah disepakati. PT PLN (Persero) dalam pelaksanaan penyerahan hak milik rumah dinas berdasarkan Pasal 25 Permen BUMN Per-02/MBU/2010 diwakili oleh Direksi ataupun penerima kuasa, diantaranya Pemimpin Unit Bisnis. ${ }^{38}$

Perjanjian penyerahan hak milik digunakan sebagai dasar pelaksanaan pelepasan hak atas tanah kepada negara. Setelah dilaksanakan pelepasan hak oleh PT PLN (Persero), maka pendaftaran tanah sudah dapat dilaksanakan oleh penghuni. Sertifikat diterbitkan atas nama penghuni rumah dinas setelah pendaftaran tanah terselesaikan. Hal tersebut memberikan kepastian bagi penghuni atas kedudukan sebagai pemilik rumah dinas.

\section{Perlindungan bagi Pembeli Rumah Dinas PT PLN (Persero) Dihubungkan dengan} Asas Kepastian Hukum

PT PLN (Persero) dan penghuni sepakat bahwa pengalihan rumah dinas dilaksanakan dengan cara sewa beli. Hal tersebut berdasarkan Pasal 1338 KUHPerdata menimbulkan akibat berupa perjanjian sewa beli berlaku mengikat bagi PT PLN (Persero) dan penghuni. Selain itu, diatur dalam Pasal 1339 KUHPerdata bahwa PT PLN (Persero) dan penghuni tidak hanya terikat ketentuan-ketentuan yang secara tergas telah disepakati, akan tetapi juga terikat ketentuan-ketentuan yang berlaku sebagai akibat dari kesepakatan sewa beli rumah dinas. Hal tersebut berlaku sebagai akibat dikualifikasikannya pengalihan rumah dinas sebagai perbuatan hukum. 39

Sewa beli rumah dinas antara PT PLN (Persero) dan penghuni dikualifikasikan sebagai perbuatan hukum diantaranya bertujuan untuk memberikan kepastian kepada para pihak yang terlibat. ${ }^{40}$ Kepastian menjadi salah satu asas hukum yang berlaku

\footnotetext{
${ }^{37}$ Rachmadi Usman, Op. Cit, hlm. 2.

${ }^{38}$ HS Salim et, al, Penerapan Teori Hukum pada Penelitian Tesis dan Disertasi, Depok: Raja Grafindo Persada, 2013, hlm. 269.

${ }^{39}$ Rahardjo, Op. Cit, hlm. 37.

${ }^{40} \mathrm{Ibid}, \mathrm{hlm}$. 40.
} 
dalam peraturan perundang-undangan. ${ }^{41}$ Kepastian tercermin dari telah ditetapkannya hak dan kewajiban karena telah diatur sebagai peraturan perundang-undangan maupun atas dasar kesepakatan. ${ }^{42}$ Kepastian salah satunya diperlukan untuk mewujudkan tujuan dari hukum berupa ketertiban. Ketertiban menjadi fakta objektif yang berlaku bagi segala masyarakat dalam segala bentuknya. 43

PT PLN (Persero) dengan penghuni secara tidak langsung terikat ketentuan jual beli sebagaimana diatur dalam KUHPerdata. Hal tersebut karena perjanjian sewa beli rumah memenuhi kualifikasi sebagai perbuatan jual beli. Suatu perbuatan dikualifikasikan sebagai jual beli berdasarkan Pasal 1457 KUHPerdata apabila terdapat kesepakatan berupa penyerahan suatu barang yang telah ditentukan beserta harga yang dibayar. ${ }^{44}$ PT PLN (Persero) sebagai penjual berdasarkan Pasal 1474 KUHPerdata terikat kewajiban berupa penyerahan dan penanggungan hak milik. Selanjutnya, penghuni berdasarkan Pasal 1513 KUHPerdata terikat kewajiban berupa pembayaran harga pada waktu dan tempat yang disepakati.

PT PLN (Persero) dan penghuni sepakat menentukan rumah dinas sebagai obyek dari perjanjian sewa beli. Rumah dinas telah ditentukan secara fisik dan yuridis oleh PT PLN (Persero) dan penghuni dimuat dalam perjanjian sewa beli. Hal tersebut berakibat penghuni tidak lagi memiliki hak penanggungan atas rumah dinas dari PT PLN (Persero). Penanggungan diatur dalam Pasal 1460 KUHPerdata bahwa jika barang yang dijual itu berupa barang yang sudah ditentukan, maka sejak saat pembelian, barang itu menjadi tanggungan pembeli, meskipun hak milik belum diserahkan.

PT PLN (Persero) dan penghuni sepakat pembayaran harga rumah dinas dilaksanakan dengan cara angsuran. Harga sewa beli rumah dinas disepakati oleh PT PLN (Persero) dan penghuni ditentukan berdasarkan taksiran pihak ketiga. ${ }^{45}$ Penentuan harga dengan penaksiran pihak ketiga dilaksanakan oleh PT PLN (Persero) berdasarkan Pasal 1465 KUHPerdata. Penaksiran oleh pihak ketiga bertujuan agar harga sewa beli rumah dinas dapat dipertanggungjawabkan oleh para pihak.

Penyerahan hak milik rumah dinas menjadi kewajiban PT PLN (Persero) dan sebaliknya hak penghuni yang timbul akibat hukum dari jual beli. Hak milik

\footnotetext{
${ }^{41}$ Rahardjo, Op. Cit, hlm. 45.

${ }^{42}$ Marzuki, (2008), Pengantar Ilmu Hukum, Jakarta: Kencana, hlm. 137.

${ }^{43}$ Salman et. al, Op. Cit, hlm. 4.

${ }^{44}$ Subekti, Op. Cit, hlm. 79.

${ }^{45} \mathrm{Ibid}, \mathrm{hlm} .16$.
} 
berdasarkan Pasal 570 KUHPerdata diartikan sebagai hak untuk menikmati suatu barang secara lebih leluasa dan untuk berbuat terhadap barang itu secara bebas sepenuhnya, asalkan tidak bertentangan dengan undang-undang atau peraturan umum yang ditetapkan oleh kuasa yang berwenang dan asal tidak mengganggu hak-hak orang lain. Hal tersebut sebagai akibat hukum baik dari berlakunya kesepakatan sewa beli ataupun jual beli. Hak milik rumah dinas berdasarkan Pasal 1459 KUHPerdata tidak dapat diperoleh penghuni sebelum diserahkan oleh PT PLN (Persero). Penyerahan hak rumah dinas disepakati dalam perjanjian sewa beli setelah kewajiban pembayaran dipenuhi oleh penghuni berdasarkan Pasal 1513 KUHPerdata. ${ }^{46}$ Hak penghuni sah berupa penyerahan hak milik rumah dinas diatur dalam Pasal 1478 KUHPerdata bahwa kewajiban penyerahan suatu barang mengikat penjual setelah pembayaran harga dipenuhi oleh pembeli. ${ }^{47}$

Biaya penyerahan hak milik rumah diantara pembuatan akta jual beli berdasarkan perjanjian sewa beli disepakati ditanggung oleh penghuni. Hal tersebut sesuai dengan Pasal 1466 KUHPerdata bahwa penghuni sebagai pembeli menanggung biaya akta jual beli dan biaya tambahan lainnya. PPAT ditunjuk oleh penghuni telah kewajiban pembayaran harga rumah dinas dipenuhi.

Penghuni berhak atas penyerahan hak milik rumah dinas sesuai yang telah ditentukan secara fisik dan yuridis sebagaimana dimuat dalam perjanjian sewa beli. Hal tersebut diatur dalam Pasal 1483 KUHPerdata bahwa PT PLN (Persero) sebagai penjual wajib menyerahkan barang sesuai yang diperjanjikan. PT PLN (Persero) berdasarkan Pasal 1484 KUHPerdata harus bersedia menerima pengurangan harga apabila tidak bisa menyerahkan barang sesuai yang diperjanjikan. Sebaliknya, penghuni berdasarkan Pasal 1485 KUHPerdata harus bersedia menerima penambahan harga atau mengajukan pembatalan harga apabila barang yang diserahkan lebih besar dari pada yang diperjanjikan.

Penghuni memiliki hak atas pemanfaatan prasarana, sarana dan utilitas rumah dinas. Prasarana, sarana dan utilitas berdasarkan Pasal 32 UU No 1 Tahun 2011 disediakan sebagai penunjang penghunian rumah dinas. PT PLN (Persero) berdasarkan Pasal 47 ayat (4) UU No 1 Tahun 2011 memiliki kewajiban penyerahan prasarana, sarana

${ }^{46}$ Satrio, (2001), Perikatan yang Lahir dari Perjanjian buku 1, Bandung: Citra Aditya Bakti, hlm. 14.
${ }^{47}$ Hasbullah, Op. Cit, hlm. 120. 
dan utilitas kepada pemerintah kabupaten/kota. Hal tersebut menjadi akibat dari pengalihan rumah dinas yang dilaksanakan oleh PT PLN (Persero).

Sewa menyewa disepakati oleh PT PLN (Persero) dan penghuni dimuat dalam perjanjian sewa beli rumah dinas. Hal tersebut dimaksudkan untuk memberikan dasar penghunian bagi penghuni sampai dengan hak milik rumah dinas diserahkan oleh PT PLN (Persero). Sewa menyewa berdasarkan Pasal 50 UU No 1 Tahun 2011 termasuk sebagai salah satu jenis hak penghunian rumah. Hak penghunian memberikan kepastian bagi penghuni dalam penghunian rumah dinas yang masih menjadi hak milik PT PLN (Persero).

Pembuatan perjanjian sewa beli dalam bentuk tertulis secara tidak langsung telah memenuhi kewajiban sebagaimana diatur dalam Pasal 28 ayat (5) PP No. 14 Tahun 2016. Diatur dalam Pasal 28 ayat (5) PP No. 14 Tahun 2016 perjanjian sewa menyewa wajib dibuat tertulis dan memuat sekurang-kurangnya hak dan kewajiban, jangka waktu sewa menyewa, dan besarnya harga sewa serta kondisi force majeure. Hak dan kewajiban dalam pelaksanaan sewa menyewa rumah dinas tidak hanya ditentukan berdasarkan kesepakatan antara PT PLN (Persero) dan penghuni, akan tetapi juga berdasarkan peraturan perundang-undangan terkait sewa menyewa. Hal tersebut karena sewa menyewa tergolong sebagai perjanjian dengan nama khusus atau perjanjian bernama yang telah diatur dalam KUHPerdata.

Sewa menyewa berdasarkan Pasal 1548 KUHPerdata dikatakan terjadi apabila terpenuhi kualifikasi berupa kesepakatan pemberian hak untuk menikmati suatu barang dengan jangka waktu tertentu disertai dengan pembayaran harga. Penghuni sebagai penyewa berdasarkan Pasal 1550 KUHPerdata memiliki hak diantara berupa hak untuk menikmati rumah dinas selama berlangsunya sewa. PT PLN (Persero) sebagai pihak yang menyewakan berdasarkan Pasal 1551 KUHPerdata memiliki kewajiban penyerahan rumah dinas yang disewakan dalam keadaan terpelihara sesuai dengan fungsi peruntukannya. Penghuni berdasarkan Pasal 1555 KUHPerdata memiliki kewajiban pemeliharaan rumah dinas selama berlangsung sewa menyewa. Selain itu, penghuni berdasarkan Pasal 1560 KUHPerdata memiliki kewajiban berupa pembayaran harga sewa yang disepakati diperhitungkan dari pembayaran harga jual beli rumah dinas yang dibayar secara bertahap atau angsuran.

PT PLN (Persero) dan penghuni sepakat bahwa sewa menyewa rumah dinas berlangsung sampai dengan penyerahan hak milik rumah dinas terlaksana. Jual beli 
berdasarkan Pasal 584 KUHPerdata tergolong sebagai peristiwa perdata sebagai penyerahan hak milik yang dilakukan terhadap orang yang berhak. Hak milik diserahkan ketika harga rumah dinas yang disepakati dibayar secara bertahap selama 5 (lima) tahun telah dibayar lunas. Pembayaran pelunasan harga rumah dinas yang dilaksanakan penghuni menimbulkan akibat hukum berupa kewajiban bagi PT PLN (Persero) untuk penyerahan hak milik kepada penghuni. Hal tersebut berakibat tidak berlakunya kewajiban pengosongan rumah dinas bagi penghuni, kecuali jika sewa menyewa disepakati diakhiri atau terjadi wanprestasi yang berakibat pada belum terlaksananya kewajiban pembayaran harga sesuai yang telah disepakati.

Penyerahan hak milik rumah dinas oleh PT PLN (Persero) kepada penghuni dijamin dengan berlakunya Pasal 1478 KUHPerdata. Hal tersebut berlaku mengikat bagi PT PLN (Persero) setelah kewajiban pembayaran harga rumah dinas dipenuhi oleh penghuni.48 PT PLN (Persero) dan penghuni dalam pelaksanaan penyerahan rumah dinas terikat ketentuan-ketentuan UU No 5 Tahun 1960. Hal tersebut karena rumah dinas tergolong sebagai hak kebendaan berupa hak atas tanah.

Hak milik berupa hak atas tanah berdasarkan Pasal 19 UU No 5 Tahun 1960 diperoleh penghuni setelah dilakukan penyerahan melalui pendaftaran tanah. Pendaftaran tanah dapat dilaksanakan penghuni berdasarkan Pasal 37 ayat (1) PP No 24 Tahun 1997 dapat dilaksanakan setelah dipenuhi persyaratan berupa pembuatan perjanjian penyerahan yang dibuat dihadapan pejabat yang berwenang dalam hal ini PPAT. Penghuni memiliki kewajiban penunjukan PPAT sebagai syarat dalam pembuatan perjanjian penyerahan. ${ }^{49}$ Kepastian penghuni sebagai pemegang hak milik diperoleh setelah penyerahan hak milik melalui pendaftaran tanah terselesaikan.

Perjanjian penyerahan hak milik rumah dinas dibuat oleh PT PLN (Persero) dan penghuni sebagai suatu perjanjian baru. Hal tersebut menimbulkan akibat hukum berupa berlakunya syarat-syarat pembuatan perjanjian sebagaimana diatur dalam peraturan perundang-undangan. Meskipun perjanjian penyerahan hak milik rumah dinas dibuat sebagai perjanjian baru, akan tetapi ditinjau dari dasar pembuatannya memiliki keterkaitan dengan perjanjian sewa beli yang telah disepakati. Perjanjian

${ }^{48}$ Rahardjo, Op. Cit, hlm. 37.
${ }^{49}$ Subekti, Op. Cit, hlm. 80. 
penyerahan hak milik rumah dinas dibuat sebagai tindak lanjut perjanjian sewa beli yang disepakati PT PLN (Persero) dan penghuni. 50

Perjanjian penyerahan hak milik rumah dinas tidak dapat dibuat oleh PT PLN (Persero) dan penghuni sebelum dipenuhi syarat-syarat yang diatur dalam peraturan perundang-undangan dan telah disepakati. ${ }^{51}$ Penangguhan pembuatan perjanjian penyerahan menjadi konsekuensi bagi PT PLN (Persero) dan penghuni, apabila belum terpenuhi syarat-syarat sebagaimana diatur dalam peraturan perundang-undangan. Hal tersebut berakibat penghuni belum diakui sebagai pemegang hak milik rumah dinas karena belum dapat dilaksanakan pendaftaran tanah dalam rangka penerbitan sertifikat. Istilah sertifikat sebagaimana dimuat dalam Pasal 1 Nomor 20 PP No 24 Tahun 1997 diartikan sebagai tanda bukti hak sebagaimana dimaksud dalam UU No 5 Tahun 1960 untuk hak atas tanah, hak pengelolaan, tanah wakaf, hak milik atas satuan rumah susun dan hak tanggungan yang masing-masing sudah dibukukan oleh instansi yang berwenang.

Penghuni telah memiliki alas hak dengan telah dipenuhinya kewajiban pembayaran harga rumah dinas berdasarkan perjanjian sewa beli. ${ }^{52}$ Alas hak merupakan dasar timbulnya hak berupa penyerahan hak milik rumah dinas. PT PLN (Persero) tidak lagi memiliki hak atas rumah dinas kecuali pelaksanaan penyerahan kepada penghuni. ${ }^{53}$ Hal tersebut berlaku sebagai akibat dari timbulnya alas hak berdasarkan perjanjian yang telah disepakati. ${ }^{54}$

Penyerahan hak milik rumah dinas dapat dituntut oleh penghuni kepada PT PLN (Persero) berdasarkan perjanjian sewa beli yang telah disepakati.55 Selain itu, penghuni juga memiliki hak untuk menuntut pembatalan sewa beli rumah dinas dengan PT PLN (Persero), apabila hak milik rumah dinas tidak diserahkan sesuai batas waktu yang telah ditentukan atas dasar kesepakatan maupun atas dasar surat peringatan. ${ }^{56}$ Pembatalan atau pengakhiran perjanjian sewa beli berdasarkan Pasal 1267 KUHPerdata dapat diajukan atas kehendak penghuni kepada PT PLN (Persero).

\footnotetext{
${ }^{50}$ Mariam Darus Badrulzaman, (2015), Sistem Hukum Benda, Bandung: Alumni, hlm. 46.

${ }^{51} \mathrm{Ibid}$.

52 Subekti, Op. Cit, hlm. 16

${ }^{53}$ Nia Kurniati, Lo. Cit.

${ }^{54}$ Van Apeldoorn, (2011), Pengantar Ilmu Hukum, Jakarta: Pradnya Paramita, hlm. 10.

${ }^{55}$ Baiq, 2016, "Akibat Hukum Jual Beli Hak atas Tanah yang Belum Didaftarkan", Jurnal IUS Vol IV, Nomor 3, hlm. 434.

${ }^{56} \mathrm{Ibid}, \mathrm{hlm} .24$.
} 
Pembatalan dapat diajukan apabila penghuni tidak lagi menuntut pelaksanaan penyerahaan hak milik rumah. Pembatalan perjanjian sewa beli rumah dinas berdasarkan perjanjian dapat dilaksanakan atas dasar kesepakatan para pihak atau putusan pengadilan. ${ }^{57}$ Penggantian biaya, kerugian dan bunga menjadi hak yang dapat dituntut oleh penghuni apabila telah disepakati pembatalan perjanjian sewa beli dengan PT PLN (Persero) dengan penghuni perjanjian sewa beli untuk dibatalkan.

\section{PENUTUP}

\section{Kesimpulan}

1. PT PLN (Persero) dan penghuni terikat hak dan kewajiban berdasarkan perjanjian sewa beli rumah dinas dan ketentuan-ketentuan yang berlaku umum dalam peraturan perundang-undangan. Hal tersebut sebagai akibat dari kualifikasi hukum atas perbuatan-perbuatan tersebut.

2. Penghuni telah memperoleh alas hak dari PT PLN (Persero) dengan telah dipenuhi kewajiban pembayaran harga rumah dians. Hal tersebut memberikan kepastian bagi penghuni berupa hak untuk menuntut penyerahan ataupun pembatalan sewa beli rumah dinas berdasarkan perjanjian yang disepakati dan peraturan perundangundangan yang berlaku.

\section{DAFTAR PUSTAKA}

\section{Buku}

Asikin, Zainal dan Suhartana, Wira Pria. (2016). Pengantar Hukum Perusahaan. Jakarta: Kencana.

Halim, A. Ridwan. (2001). Hukum Pemukiman, Perumahan dan Rumah Susun, Jakarta: Doa\& Karma.

Miru Ahmadi dan Pati Sakka. (2012). Hukum Perikatan: Penjelasan Makna Pasal 1313 sampai 1456 BW. Jakarta: Rajawali Pers.

Muhammad, Abdulkadir. (1982). Hukum Perikatan, Bandung: Alumni.

Hamzah, Andi et.al. (1990). Hukum Perumahan. Jakarta: Rineka Cipta.

Kansil, C.S.T. (2018) Pengantar Ilmu Hukum dan Tata Hukum Indonesia, Jakarta: Balai Pustaka.

\footnotetext{
${ }^{57}$ Baswedan, 2013, “Kajian Yuridis Pembatalan Akta Pengikatan Jual Beli (PJB) yang dibuat dihadapan Notaris," Tesis, Fakultas Hukum Universitas Sumatera Utara, Medan, hlm. 59.
} 
Hasbullah, Frieda Husni. (2002). Hukum Kebendaan Perdata. Jakarta: Ind.hill.

Satrio, J., (2001). Hukum Perikatan. Perikatan yang Lahir dari Perjanjian buku 1. Bandung: Citra Aditya Bakti.

Sidabalok, Janus. (2012). Hukum Perusahaan, Bandung: Nuansa Aulia.

Apeldoorn, L.J Van. (2011). Pengantar Ilmu Hukum, Jakarta: Pradnya Paramita.

Salman, Otje dan Damian, Eddy. (2013). Kumpulan Karya Tulis Mochtar Kusumaatmaja tentang konsep-konsep hukum dalam pembangun. Bandung: Alumni.

Marzuki, Peter Mahmud. (2008). Pengantar Ilmu Hukum. Jakarta: Kencana.

Marzuki, Peter Mahmud. (2016). Penelitian Hukum. Jakarta: Kencana.

Suryodiningrat, R. M. (1979). Azas-azas hukum perikatan. Bandung: Tarsito.

Prodjodikoro, R. Wirjono. (2010). Azas-Azas Hukum Perjanjian. Bandung: Mandar Maju. Hartini, Rahayu. (2017) BUMN Persero: Konsep Keuangan Negara dan Hukum Kepailitan di Indonesia. Setara Press: Malang.

Usman, Rachmadi. (2011). Hukum Kebendaan. Jakarta: Sinar Grafika.

HS, Salim dan Nurbani, Erlies Septiana. (2013). Penerapan Teori Hukum pada Penelitian Tesis dan Disertasi. Depok: Raja Grafindo Persada.

Rahardjo, Satjipto. (2010). Ilmu Hukum, Bandung: Citra Aditya Bakti.

Soekanto, Soerjono dan Mamuji, Sri. (2010). Penelitian Hukum Normatif Suatu Tinjauan Singkat. Jakarta: Raja Grafindo Persada.

Subekti. (2014). Hukum Perjanjian. Jakarta: Intermasa.

Sugiyono. (2009). Metode Penelitian Kualitatif, Bandung: Alfabeta.

Santoso, Urip. (2014). Hukum Perumahan. Jakarta: Kencana.

\section{Jurnal}

Rokfa, Afida Ainur. (2020). Kedudukan Hukum Kekayaan BUMN Persero dalam Pelaksanaan Sita Umum sebagai Akibat Terjadinya Kepailitan. Jurnal Ilmu Kenotariatan, 1 (1).

Adhari, Agus. (2015). Eksistensi BUMN sebagai Korporasi yang Dikuasai Negara. Dialogia Iuridica, 7 (1).

P., Agung et.al. (2018) Masalah Keagenan dan Kepemilikan Pemerintah Serta Dampak Keuangan Negara atas Implementasi ISAJK 8 (Studi Kasus PT PLN (Persero). Simposium Nasional Keuangan Negara, 1 (1). 
Paramita, Ariana Ratna et.al. (2016). Wanprestasi dalam Perjanjian Pengikatan Jual Beli Tahap dan Bangunan (Studi Penelitian pada Pengembang Kota Semarang). Diponegoro Law Journal, 5 (3).

H.P.R., Baiq. (2016). Akibat Hukum Jual Beli Hak atas Tanah yang Belum Didaftarkan. Jurnal IUS, IV (3).

Orchad, Christian. (2016). Penerapan Good Corporate Governance dalam Upaya Mewujudkan BUMN yang Berbudaya. Jurnal Hukum Samudera Keadilan, 11 (2).

Rondonuwu, Giovanni. (2017). Kepastian Hukum Peralihan Hak atas Tanah melalui Jual Beli Berdasarkan PP Nomor 24 Tahun 1997 tentang Pendaftaran Tanah", Lex Privatum, V (4).

G.M., Intan et.al. (2019). Kepemilikan Rumah Dinas oleh Purnawirawan TNI Berdasarkan Perundang-Undangan. Law Review, XIX (1).

Wijaya, Ivan Satria. (2015). Pertanggungjawaban Pengurusan Badan Usaha Milik Negara Terhadap Kerugian Keuangan Negara pada Pengelolaan Persero. Jurnal Ilmiah Mahasiswa Universitas Surabaya, 4 (2).

Bawarodi, Jeinal. (2014). Penerapan Perjanjian Sewa Beli di Indonesia dan Akibat Hukumnya. Lex Privatum, II (3).

Kusmono. (2016). Pembelaan melalui Prinsip-Prinsip Business Judgement Rule Bagi Direksi BUMN Persero Bila Terjadi Kerugian. Ilmu Artha, 3.

A.D.A.A, Made. (2019). Perjanjian Pengikatan Jual Beli (PPJB) dalam Transaksi Peralihan Hak atas Tanah dan/atau Bangunan. Kertha Semaya, 8 (1).

Kurniati, Nia. (2018). Pengalihan Hak Rumah Negara kepada Pegawai Negeri dalam Penerapan Hukum Sewa Beli. Jurnal Bina Mulia Hukum, 2 (2).

Kurniati, Nia. (2014). Pemenuhan Hak atas Perumahan dan Kawasan Permukiman yang Layak dan Penerapannya Menurut Kovenan Internasional tetang Hak-Hak Ekonomi. Sosial dan Budaya di Indonesia. Padjadjaran Jurnal Ilmu Hukum, 1 (1).

A.R, Rifan et.al. 2017. Kesadaran Hukum Masyarakat dalam Jual Beli Tanah dengan Akta PPAT di Kecamatan Tinanggea Kabupaten Konawe Sulawesi Tenggara. Jurnal Akta, 4 (3). 


\section{Peraturan Perundang-Undangan}

Undang-Undang Dasar 1945.

Kitab Undang-Undang Hukum Perdata.

Undang-Undang Nomor 5 Tahun 1960 tentang Peraturan Dasar Pokok-Pokok Agraria.

Undang-Undang Nomor 17 Tahun 2003 tentang Keuangan Negara.

Undang-Undang Nomor 19 Tahun 2003 tentang Badan Usaha Milik Negara.

Undang-Undang Nomor 40 Tahun 2007 tentang Perseroan Terbatas.

Undang-Undang Nomor 1 Tahun 2011 tentang Permukiman dan Kawasan Perumahan.

Peraturan Pemerintah Nomor 40 Tahun 1994 tentang Rumah Negara.

Peraturan Pemerintah Nomor 14 Tahun 2016 tentang Penyelenggaraan Perumahan dan Kawasan Permukiman.

Peraturan Menteri Negara Badan Usaha Milik Negara Nomor Per-02/MBU/2010 tentang Tata Cara Penghapusan dan Pemindahtanganan Aktiva Tetap Badan Usaha Milik Negara yang telah diubah 2 (dua) kali dengan Peraturan Menteri Negara Badan Usaha Milik Negara Nomor Per-06/MBU/2010 dan Peraturan Menteri Negara Badan Usaha Milik Negara Nomor Per-22/MBU/12/2014 (selanjutnya disebut Permen BUMN No. Per-02/MBU/2010).

\section{Sumber Lain}

Agustina, Rima. (2017). “Kedudukan Hukum Sewa Beli dalam Peralihan Hak atas Tanah dan Bangunan Studi atas Sewa Beli antara PT PLN (Persero) Wilayah Sumbagut dengan Karyawan." Tesis. Fakultas Hukum Universitas Sumatera Utara. Medan.

Baswedan, T. 2013. "Kajian Yuridis Pembatalan Akta Pengikatan Jual Beli (PJB) yang dibuat dihadapan Notaris." Tesis. Fakultas Hukum Universitas Sumatera Utara. Medan.

M.I.B, Barnok. 2011. “Tanggung Jawab Direksi dalam Pelepasan Aset Tidak Bergerak pada Badan Usaha Milik Negara." Tesis. Fakultas Hukum Universitas Sumatera Utara. Medan.

Angelina. 2012. “Tinjauan Yuridis Terhadap Pembatalan Perjanjian Pengikatan Jual Beli (PPJB) yang dibuat oleh Notaris yang telah sesuai dengan wilayah kewenangannya (studi kasus putusan pengadilan negeri jakarta utara nomor 260/PDT.G/2002/PN.JKT.PST." Tesis. Fakultas Hukum Universitas Indonesia.Depok.

A.P.D, Amalia. “Analisis Yuridis Terhadap Perjanjian Sewa Beli Rumah Negara di Kota Medan." Tesis. Fakultas Hukum Universitas Sumatera Utara. Medan. 